\title{
TIPOLOGI NILAI-NILAI MOTIVASI PELAYANAN PUBLIK DI PDAM KABUPATEN MAMASA
}

\author{
Oktovianus $^{1}$ \\ ${ }^{1}$ Prodi Ilmu Pemerintahan, Fakultas Ilmu Sosial dan Ilmu Pemerintahan \\ Universitas Al Asyariah Mandar \\ Email: oktovianus@gmail.com \\ Aco Dahrul Saharuddin² \\ ${ }^{1}$ Prodi Ilmu Pemerintahan, Fakultas Ilmu Sosial dan Ilmu Pemerintahan \\ Universitas Al Asyariah Mandar \\ Email: aco_dahrul@gmail.com
}

\section{ABSTRACT}

This study aims to determine the value of the typology of motivation for public services in PDAM Mamasa Regency. Research is carried out systematically, factually and accurately regarding the facts and facts of certain populations. The results show that the typology of the value of public service motivation is commitment to the public interest; empathy; and self-sacrifice of relatively high value. Meanwhile, the value of the importance of public policy making is relatively low compared to other values. The value of interest in public policy making is the lowest proportion. Commitment to the greatest presentation public interest. The second largest percentage value of empathy. The value of self-sacrifice obtained in the third presentation.

\begin{abstract}
ABSTRAK
Penelitian ini bertujuan untuk mengetahui nilai tipologi nilai-nilai motivasi pelayanan publik di PDAM Kabupaten Mamasa. Penelitian dilakukan secara sistematis, faktual dan akurat mengenai fakta dan karakteristik populasi tertentu. Hasil menunjukkan Tipologi nilai motivasi pelayanan publik adalah komitmen untuk kepentingan umum; empati; dan pengorbanan diri dengan nilai yang relatif tinggi. Sedangkan nilai kepentingan pembuatan kebijakan publik relatif rendah dibandingkan ketiga nilai lainnya. Nilai kepentingan dalam pembuatan kebijakan publik mendapatkan persentase terendah. Komitmen terhadap kepentingan umum diperoleh presentasi terbesar. Nilai empati diperoleh persentase terbesar kedua. Nilai pengorbanan diri yang didapat pada presentasi ketiga.
\end{abstract}

Kata Kunci: Tipologi, Nilai, Motivasi dan Pelayanan Publik, PDAM 


\section{PENDAHULUAN}

Penyelenggaraan pelayanan publik merupakan upaya negara untuk memenuhi kebutuhan dasar dan hak-hak sipil setiap warga negara atas barang, jasa, dan pelayanan administrasi yang disediakan oleh penyelenggara pelayanan publik. Seperti yang disebutkan Hamdan (2019) bahwa ruang publik merupakan elemen pokok dari suatu Negara bangsa. Semakin sehat ruang publiknya, semakin sehat pula Negara itu berjalan, begitu pula sebaliknya.

Di Indonesia, Undang-Undang Dasar 1945 (UUD1945) mengamanatkan kepada negara agar memenuhi kebutuhan dasar setiap warganya demikesejahteraannya, sehingga efektivitas suatu sistem pemerintahan sangat ditentukan oleh baik buruknya penyelenggaraan pelayanan publik.

Pemenuhan hak dasar dan kebutuhan masyarakat oleh pemerintah, juga termuat dalam sila-sila yang terkandung dalam Pancasila terutama sila ke-2, kemanusian yang adil dan beradab dan sila ke-5, keadilan sosial bagi seluruh rakyat Indonesia. Konstitusi dan ideologi tersebut menjadi pedoman bagi pemerintah sebagai upaya mendukung terciptanya pelayanan publik yang prima dalam sistem pemerintahan.

Undang-Undang No. 32 Tahun 2004 tentang Pemerintahan Daerah, diharapkan dapat memberikan dampak secara nyata yang luas dan bertanggungjawab dalam penyelenggaran pemerintahan yang efektif dan efisien guna meningkatkan pemberian layanan kepada masyarakat. Dengan adanya pelimpahan wewenang dari Pemerintah Pusat ke Daerah melalui kebijakan desentralisasi, dekosentrasi dan tugas pembantuan memungkinkan terjadinya pelayanan dengan jalur birokrasi yang lebih mudah.

Seiring dengan perkembangan zaman, tuntutan masyarakat atas pelayanan yang berkualitas tidak dapat terelakkan. Hal ini adalah wajar mengingat sumber penerimaan negara terbesar adalah pungutan pajak dari masyarakat. Hal ini sepatutnya menjadi pendorong bagi pemerintah untuk dapat meningkatkan kinerjanya dalam penyelenggaraan pelayanan publik.

Upaya peningkatan kualitas penyelenggaraan pelayanan publik secara mikro telah diatur dalam UU No.25 tahun 2009 tentang Pelayanan Publik. Undang-undang ini memuat asas, tujuan, ruang lingkup, aspek penyelenggaraan hingga sanksi dalam penyelenggaraan pelayanan publik yang kemudian diturunkan kedalam peraturan - peraturan lain di setiap daerah hingga instansi terkait. Sedangkan secara makro, peningkatan kualitas pelayanan publik dituangkan dalam UU No. 32 tentang Otonomi Daerah. Undang-undang ini pada hakekatnya berfungsi untuk menghilangkan jarak antara pemerintah dan masyarakat dalam pemenuhan kebutuhan-kebutuhan masyarakat demi terwujudnya kesejahteraan bagi seluruh rakyat indonesia. 
Salah satu poin penting yang dapat meningkatkan kinerja seorang pegawai dalam menjalankan tugasnya ialah motivasi. G.R. Terry (dalam Drs.H. Malayu S.P. Hasibuan, 2002;145) mengemukakan bahwa motivasi adalah keinginan yang terdapat pada diri seseorang individu yang merangsangnya untuk melakukan tindakan-tindakan.

Di indonesia upaya yang dilakukan oleh pemerintah berkaitan dengan peningkatan kualitas pelayanan publik dari aspek manusia ialah dengan kebijakan remunerasi. Kebijakan remunerasi merupakan salah satu produk dari Program Reformasi Birokrasi yang bertujuan untuk meningkatkan motivasi kerja pegawai negeri Indonesia. Banyak pihak yang berpendapat bahwa materi atau uang/gaji adalah faktor yang sangat dominan mempengaruhi kinerja seorang pegawai. Pandangan tersebut adalah kekeliruan cara pandang karena materi adalah bukanlah satu-satunya yang mampu memotivasi pegawai. Bahkan jika kita telah kembali kebijakan pemerintah dalam memberikan tunjangan bagi pegawai, hal ini tidak cukup memberikan kontribusi dalam peningkatan kinerja pegawai. Dalam bidang pendidikan misalnya, sertifikasi guru tidak cukup membantu dalam meningkatkan presentase kelulusan peserta didiknya. Di tingkat SMA presentase kelulusan pada tahun 2015 mencapai $99,52 \%$, capaian ini turun $0,01 \%$ dari tahun sebelumnya. Hal ini menunjukkan bahwa buruknya pelayanan bagi masyarakat tidak sepenuhnya dipengaruhi oleh faktor motivasi yang berupa materi tetapi ada hal lain yang tidak cukup diperhatikan memberikan dampak yang signifikan terhadap pelayanan yakni motivasi yang tidak berupa materi.

Motivasi pelayanan publik membangun teori motivasi yang berasal dari tiga jenis motif yakni; afektif, normatif, dan rasional. Dari dimensi afektif, hal ini diklaim bahwa individu tertarik pada pelayanan publik seperti keyakinan tentang pentingnya pelayanan publik. Dimensi normatif menunjukkan daya tarik didasarkan pada alasan etis seperti ekuitas dan keadilan, sedangkan dimensi rasional menunjukkan dasar yang sejalan dengan kepentingan individu untuk tertarik pada pembuatan kebijakan untuk mempromosikan kepentingan publik (Perry dan Wise 1990).

Berdasarkan kerangka teori Motivasi Pelayanan Publik yang dikembangkan oleh Perry (1990) ada 4 dimensi yang dimiliki oleh seorang pegawai sektor publik yaitu: 1) Ketertarikan Terhadap Pembuatan Kebijakan Publik (Attraction to Public Policy Making), 2) Tanggung Jawab Terhadap Kepentingan Publik (Commitment To Public Interest), 3) Perasaan Simpati Atau Kasihan (Compassion), dan 4) Pengorbanan Diri (Self Sacrifice).

Konsep Motivasi Pelayanan Publik adalah konsep yang interaktif dan dibentuk oleh tiga domain, yaitu institusi, pegawai sektor publik/PNS, dan perilaku. Perilaku sebagai acuan penilaian terhadap pelayanan adalah citra 
(image) yang keluar sebagai output dari budaya organisasi dan karakter individu pegawai. Perilaku merupakan wujud dari perpaduan antara budaya, system dan mekanisme kerja yang ditransmisikan kepada masing-masing pegawai sektor publik dan berkolaborasi dengan ciri atau watak pegawai itu sendiri (Wahyu Eko Yudiatmaja, 2012;212).

Fenomena yang terjadi dalam penyelenggaraan pelayanan publik di Indonesia kurang lebih menunjukkan rendahnya motivasi pelayanan publik dari para penyelenggara pelayanan publik. Hal ini dapat dilihat dari permasalahan yang banyak dikeluhkan masyarakat ialah perilaku pegawai sektor publik yang tidak mencerminkan bagaimana seharusnya seorang pelayan masyarakat bertindak. Ketika seorang pegawai sektor publik memiliki Motivasi pelayanan publik yang baik itu artinya tidak akan ada lagi perilaku yang menimbulkan permasalahan bagi masyarakat karena perilakunya adalah cerminan institusi dan pribadinya (Syamsir dan Muhammad Ali Embi, 2011).

Pegawai sektor publik yang memiliki motivasi pelayanan publik yang tinggi tentunya akan menghasilkan pelayanan yang prima bagi masyarakat. Pelayanan prima (Atep Adya Brata, 2003;27) adalah pelayanan yang mengutamakan kepuasan pelanggan, membuat pelanggan merasa penting, melayani pelanggan dengan ramah, tepat dan cepat, pelayanan yang menempatkan pelanggan sebagai mitra, kepedulian kepada pelanggan untuk memberikan rasa puas

Dalam pelaksanaannya, masih menemui permasalahan-permasalahan yang cukup mengkhawatirkan dan menggambarkan kurang maksimalnya kinerja Dinas PDAM Kabupaten Mamasa. Permasalahan yang masih menjadi keluhan masyarakat terkait pelayanan, yaitu keterlambatan dalam menangani kebutuhan kebutuhan masyarakat atas pelayanan yang diberikan

\section{METODE PENELITIAN}

Jenis penelitian yang digunakan oleh peneliti berdasarkan tujuan penelitian adalah penelitian deskriptif, yaitu penelitian yang dilakukan untuk mengetahui nilai variabel mandiri, baik satu variabel atau lebih tanpa membuat perbandingan. Penelitian deskriptif dibuat secara sistematis, faktual dan akurat mengenai fakta-fakta dan sifat-sifat populasi tertentu. Berdasarkan teknik pengumpulan data, peneliti menggunakan penelitian survei, dimana dalam penelitian ini penelitian mengajukan pertanyaan tertulis, baik yang telah tersusun dalam kuisioner 


\section{HASIL PENELITIAN}

\section{Tipologi Nilai-Nilai Motivasi Pelayanan Publik}

Motivasi Pelayanan Publik ialah motivasi yang mencakup kepercayaan, nilai, dan sikap yang melampaui kepentingan pribadi dan kepentingan organisasi, mendorong seorang pekerja (pegawai) untuk berbuat baik kepada orang lain dan menyumbangkan darma baktinya kepada kesejahteraan organisasi dan masyarakat. Terdapat 4 (empat) nilai-nilai dalam motivasi pelayanan publik yakni ketertarikan terhadap pembuatan kebijakan publik, komitmen pada kepentingan publik, rasa empati dan pengorbanan diri. Dari keempat nilai inilah dapat dilihat bagaimana tipologi motivasi pelayanan publik pada sebuah instansi pemberi pelayanan publik.

Adapun permasalahan yang terjadi di PDAM Kabupaten Mamasa ialah keterlambatan penyelesaian pelayanan dan adanya pungutan liar (pungli). Berdasarkan observasi yang dilakukan oleh peneliti kedua kasus ini adalah permasalahan yang paling dikeluhkan oleh masyarakat. Keterlambatan penyelesaian pelayanan yang dirasakan oleh masyarakat umumnya 2-3 hari dari waktu yang dijanjikan oleh pegawai. Umumnya masyarakat mengurus surat izin usaha dan surat izin mendirikan bangunanlah yang mengeluhkan hal ini. Selain itu, peneliti menemukan permasalahan pungutan liar (pungli) dalam pemberian pelayanan bagi masyarakat. Para pengguna layanan mengeluhkan adanya biaya-biaya tambahan yang harus diberikan kepada pegawai atas izin yang diurus masyarakat. Ketika dikonfirmasi kepada bagian informasi dan pengaduan PDAM Kabupaten Mamasa kedua permasalahan ini memang menjadi citra negatif instansi yang selalu diupayakan untuk dihilangkan.

Berdasarkan kondisi aktual yang diperoleh dari PDAM Kabupaten Mamasa dari 4 nilai terdapat 1 nilai dengan tingkatan sedang dan 3 nilai lainnya dengan tingkatan tinggi. Maka dapat diketahui tipologi motivasi pelayanan publik di PDAM Kabupaten Mamasa ialah Komitmen pada kepentingan Publik, Rasa Empati dan Pengorbanan Diri. Jika mengacu kepada teori motivasi pelayanan publik yang disampaikan oleh James L.Perry, Hal ini menunjukkan bahwa pegawai PDAM Kabupaten Mamasa adalah instansi yang berkomitmen pada kepentingan publik, memiiliki rasa empati dan rasa pengorbanan diri dalam memberikan pelayanan publik bagi masyarakat.

Selain itu, hal ini juga menunjukkan bahwa PDAM Kabupaten Mamasa memiliki kepercayaan, nilai dan sikap untuk melayani masyarakat dengan baik tanpa menempatkan kepentingan pribadi maupun kepentingan organisasi diatas kepentingan masyarakat. Pada hakekatnya, pegawai sebagai abdi masyarakat memang sudah seharusnya memiliki motivasi 
pelayanan publik yang tinggi agar mampu memberikan kepuasan terhadap pelayanan yang diberikan bagi masyarakat.

Berdasarkan hasil penilaian kuesioner, maka dapat dilihat bahwa secara umum PDAM Kabupaten Mamasa telah memiliki motivasi pelayanan publik yang baik. Namun, jika dikaitkan dengan permasalahan yang banyak dikeluhkan oleh masyarakat yakni adanya pungutan liar (pungli) atas pelayanan yang dibutuhkan oleh masyarakat dan terjadinya keterlambatan penyelesaian pelayanan. Jika sebuah organisasi telah memiliki motivasi pelayanan publik yang baik, tentunya hal semacam ini tidak akan terjadi. Kurangnya profesionalisme, beragamnya watak dan karakter pegawai pemberi layanan serta kurangnya pengorbanan diri terhadap masyarakat ialah penyebab motivasi pelayanan publik belum mampu diimplementasikan dengan optimal pada masyarakat.

\section{Ketertarikan terhadap pembuatan kebijakan publik}

Ketertarikan pada pembuatan kebijakan publik (Attraction to public policy making), menurut Perry dan Wise erat kaitannya dengan motivasi untuk mencapai prestasi. Kebijakan publik ialah pilihan pemerintah atas program yang akan dilakukan bagi masyarakat yang mempengaruhi motivasi seorang pegawai untuk mencapai prestasi dalam bekerja.

Dalam teorinya, Perry (1990) mengungkapkan bahwa Seorang pegawai yang bermotivasi pelayanan publik yang tinggi memiliki pandangan positif terhadap proses politik dalam pembuatan kebijakan publik, memiliki ketertarikan terhadap kehidupan para politisi dan memiliki ketertarikan pada proses yang bersih dalam proses politik pembuatan kebijakan publik.

Pandangan positif terhadap proses pembuatan kebijakan publik berkorelasi secara positif terhadap sikap dan perilaku seorang pegawai dalam melaksanakan tugasnya. Hal ini dapat dilihat ketika seorang pegawai memiliki pandangan yang positif terhadap pembuatan kebijkan publik itu artinya sebagai seorang pelaksana kebijakan publik ia yakin dan percaya bahwa apa yang dikerjakan adalah sebuah hal yang positif dan bermanfaat bagi masyarakat. Ketertarikan pada kehidupan para politisi seorang pegawai juga berdampak kepada sikap dan perilaku pegawai karena pribadi dan karakter politisi yang baik akan berdampak positif pula bagi motivasi kerja seorang pegawai untuk dapat berperilaku kerja sama ataupun melebihi karakter dari politisi tersebut. Setiap pegawai tentunya mampu memilah dan memilih dengan baik pribadi yang pantas untuk dijadikan tauladan dalam bekerja. Sedangkan Ketertarikan pada hal memberi dan menerima "take and give" dalam pembuatan kebijakan publik akan berkorelasi positif terhadap kinerja seorang pegawai. Hal ini dikarenakan memberi dan menerima dalam pembuatan kebijakan publik bagi kesejahteraan masyarakat dapat memacu 
perilaku kerja seorang pegawai yang pada hakekatnya bekerja untuk mewujudkan kesejahteraan bagi masyarakat.

Kondisi aktual yang terjadi di PDAM Kabupaten Mamasa ialah tingkat ketertarikan responden (pegawai) terhadap pembuatan kebijakan publik tergolong sedang. Hal ini dpat dilihat dari jawaban terhadap 3 buah pertanyaan tentang ketertarikan pembuatan kebijakan publik yang diajukan. Ketiga pertanyaan tersebut dijawab dengan tingkatan sedang. Hal ini membuktikan bahwa pegawai tidak begitu tertarik dengan pembuatan kebijakan publik. Hal ini didukung pula dengan hasil wawancara dengan kepala bagian kepegawaian PDAM Kabupaten Mamasa ( Daniel Boggakaiyyang, $S E$ ) yang menyatakan bahwa sebagian besar pegawai tidak begitu tertarik dengan kebijakan pemerintah secara umum, para pegawai hanya fokus terhadap perintah ataupun tugas yang diberikan oleh atasannya masing-masing. Hal ini menunjukkan bahwa ketertarikan pegawai hanya berada pada level tugas dan perintah dari atasan masing-masing bagian. Salah Seorang pegawai (Alfian (27 tahun) menjelaskan bahwa ketidaktertarikan mereka diakibatkan karena sebagian besar waktu mereka telah tersita untuk melaksanakan tugas yang diberikan.

\section{Komitmen pada kepentingan publik}

Komitmen pada kepentingan publik (Commitmen to public interest) adalah motif atau keinginan untuk melayani kepentingan publik yang dapat berupa kepentingan individu dalam program atau pelayanan publik tertentu indikatornya adalah sikap kasih sayang atau keyakinan yang tulus terhadap kepentingan sosial. Komitmen yang seharusnya dimiliki oleh seorang pegawai bukan hanya komitmen untuk organisasinya saja melainkan harus memiliki komitmen kepada kepentingan publik.

Dalam teorinya, Perry (1990) menulis bahwa dalam motivasi pelayanan publik seorang pegawai haruslah memiliki keyakinan dan kepercayaan penuh terhadap tugas dan tanggung jawabnya untuk selalu menempatkan kepentingan publik diatas kepentingan pribadi maupun kepentingan golongan. Hal ini menyiratkan makna dari seorang abdi masyarakat yang sesungguhnya karena, seorang pegawai adalah pelayan masyarakat yang sudah seharusnya mengabdikan dirinya untuk kesejahteraan masyarakat. Seorang pegawai yang memiliki komitmen pada kepentingan publik yang tinggi memiliki ketertarikan terhadap hal-hal yang terjadi dilingkungan sekitarnya, berkontribusi terhadap lingkungan sekitar tanpa ada rasa egois, memiliki kesadaran akan pentingnya makna pelayanan publik, mampu menempatkan kepentingan masyarakat diatas kepentingan diri sendiri, dan memiliki kesadaran bahwa pelayanan publik adalah tanggung jawab terhadap negara. 
Secara umum, untuk menilai komitmen pada kepentingan publik ini dapat kita lihat bahwa pegawai PDAM Kabupaten Mamasa sudah tergolong baik, namun jika dihubungkan dengan permasalahan yang terjadi maka secara normatif nilai ini belum mampu diaplikasikan dengan baik.

\section{Rasa Empati}

James L.Perry menuliskan bahwa seorang pegawai yang memiliki rasa empati yang tinggi memiliki perasaan empati terhadap nasib orang-orang yang kurang beruntung, memiliki ketertarikan terhadap program-program sosial, memiliki perasaan iba ketika melihat orang lain dalam kesusahan, memiliki kesadaran bahwa patriotisme adalah bagaimana melihat orang lain sejahtera, memiliki perhatian terhadap kesejahteraan orang lain meskipun tidak dikenal secara personal, memiliki kesadaran bahwa hidup kita selalu bergantung terhadap satu sama lain, memiliki perasaan kasihan terhadap orang-orang yang tidak mau membantu dirinya sendiri, dan selalu memberi dukungan terhadap program-program untuk kepentingan publik.

Kondisi aktual yang terjadi di PDAM Kabupaten Mamasa ialah tingkat rasa empati tergolong tinggi. Hal ini dapat dilihat dengan jawaban dari 8 buah pertanyaan yang rata-rata dijawab dengan skor 4 atau dalam skala likert tergolong tinggi. Jika mengacu kepada teori motivasi pelayanan publik, kondisi ini sudah mampu memotivasi pegawai dalam memberikan pelayanan publik bagi masyarakat. Sudah seharusnya seorang pegawai terlebih bagi pegawai yang memberikan pelayanan publik bagi masyarakat untuk memiliki rasa empati dalam melaksanakan tugasnya karena, hal inilah yang menjadi dasar seorang pegawai untuk mampu memberikan pelayanan yang terbaik bagi masyarakat.

Secara umum, nilai rasa empati di PDAM Kabupaten Mamasa sudah baik (berdasarkan hasil kuesioner) namun, jika dikaitkan dengan permasalahan yang diperoleh dari berbagai media kondisi ini kurang lebih menggambarkan masih buruknya rasa empati pegawai pada instansi ini. Ketika dikonfirmasi dengan beberapa pegawai (Depparinding (39 tahun), Adam S, S.Kom (35 tahun) dan Esra Bataragoa (30 tahun)), mereka menjelaskan bahwa rasa empati mereka kepada masyarakat tidak seluruhnya baik dikarenakan tidak semua pegawai memilik hati dan jiwa penolong meskipun pegawai memiliki jiwa penolong belum tentu ia mau menolong semua masyarakat, dengan alasan waktu dan tenaga yang terbatas, ini bukanlah hal yang seharusnya dilakukan oleh seorang abdi masyarakat dan hal inilah yang menjadi penyebab rasa empati tersebut sulit untuk diimplementasikan secara optimal kepada masyarakat.

2. Pengorbanan Diri 
James.L.Perry menuliskan bahwa seorang pegawai yang memiliki rasa pengorbanan diri yang tinggi memiliki karakteristik yakni memiliki keyakinan bahwa membuat perubahan masyarakat lebih berarti dibandingkan dengan membuat prestasi pribadi, selalu mendahulukan tugas kantor dibandingkan kepentingan diri sendiri, selalu mengutamakan pemberian pelayanan yang baik kepada masyarakat dibandingkan pemenuhan kebutuhan finansial, memiliki pandangan bahwa apa yang dikerjakan adalah untuk kepentingan yang lebih besar bukan untuk kepentingan dirinya sendiri, memiliki perasaan senang ketika melayani masyarakat meskipun tidak ada imbalan untuk itu, memiliki pandangan bahwa kita harus lebih banyak memberi kepada masyarakat dibandingkan apa yang telah masyarakat berikan, rela mengambil resiko untuk kepentingan orang lain, dan siap berkorban demi kepentingan masyarakat.

Nilai pengorbanan diri PDAM Kabupaten Mamasa berdasarkan hasil penilaian kuesioner tergolong baik, namun jika melihat permasalahan yang banyak dikeluhkan masyarakat yakni adanya pungutan liar dan keterlambatan penyelesaian layanan dapat dilihat bahwa para pegawai tidak memiliki rasa pengorbanan diri bagi masyarakat. Ketika dikonfirmasi dengan beberapa pegawai (Mardonal. B (39 tahun), Pilon (30 tahun), dan Paillin,S.Sos (40 tahun) yang memberikan pelayanan bagi masyarakat, mereka mengungkapkan bahwa pengorbanan diri memang seharusnya dilakukan oleh seorang pegawai namun, kita harus tetap memperhatikan diri sendiri, karena jika kita bekerja tanpa memperdulikan kesehatan dan kebugaran jiwa dan fikiran diri sendiri maka, pekerjaan tidak akan ada yang mampu terselesaikan.

\section{KESIMPULAN}

Berdasarkan hasil penelitian yang telah dibahas pada bab sebelumnya, maka dapat ditarik kesimpulan bahwa: tipologi nilai-nilai motivasi pelayanan publik di PDAM ( Perusahaan Daerah Air Minum ) Kabupaten Mamasa ialah komitmen pada kepentingan publik, rasa empati dan pengorbanan diri dengan nilai relatif tinggi. Sedangkan nilai ketertarikan pada pembuatan kebijakan publik pada PDAM Kabupaten Mamasa relatif rendah dibandingkan ketiga nilai lainnya. Nilai ketertarikan pada pembuatan kebijakan publik memperoleh presentase terendah dengan perolehan 348 atau $58 \%$ dari nilai maksimum pada variabel ini. Nilai komitmen pada kepentingan publik memperoleh presentasi terbesar dengan perolehan 797 atau $79,7 \%$ dari nilai maksimum pada variabel ini. Nilai rasa empati memperoleh presentase kedua terbesar dengan perolehan 1247 atau 77,93\% dari nilai maksimum pada variabel ini. Nilai Pengorbanan diri memperoleh presentasi ketiga dengan perolehan 1234 atau $77,125 \%$ dari nilai maksimum pada variabel ini 


\section{SARAN}

Secara umum, agar nilai-nilai motivasi pelayanan publik dapat di terapkan di PDAM Kabupaten Mamasa maupun instansi lainnya, nilai-nilai ini harus diterapkan mulai dari rekruitmen pegawai. Pemilihan pegawai tidak hanya harus memperhatikan kecerdasan intelektual seorang pegawai tetapi juga harus memperhatikan nilai-nilai perilaku prososial yang terkandung dalam motivasi pelayanan publik. Jika hal ini dapat dilakukan, maka pegawai yang terjaring adalah pegawai yang benar-benar berorientasi kepada kepentingan dan kesejahteraan masyarakat

\section{DAFTAR PUSTAKA}

Batinggi A dan Badu Ahmad. 2013. Manajemen Pelayanan Publik. Yogyakarta: Andi Offset

Sugiyono. 2012. Metode Penelitian Administrasi. Bandung. CV.Alfabeta.

Dwiyanto, Agus. 2012. Manajemen Pelayanan Publik: Peduli, Inklusif, dan Kolaboratif. Yogyakarta. Gadjah Mada University Press.

Ghozali, I. 2006. Aplikasi Analisis Multivariat dengan Program SPSS. Edisi 3. BPUndip. Semarang

Hamdan, H., \& Ikhsan, M. I. M. (2019). The Future of Public Spaces and Inclusive Islam. PROCEEDING IAIN Batusangkar, 4(1).

Istianto, Bambang. 2009. Manajemen Pemerintah dalam Perspektif Pelayanan Publik. Jakarta: Mitra Wacana Media

Rakhmat. 2009. Teori Administrasi dan Manajemen Publik. Jakarta: Pustaka Arif

Surjadi. 2009. Pengembangan Kinerja Pelayanan Publik. Bandung: Refika

Aditama

Perry, James L. And Annie Hondeghern, eds. 2008. Motivation in Public Management: The Call of Public Service. Oxford: Oxford University Press.

Ratminto dan Atik Septi Winarsih. 2008. Manajemen Pelayanan. Yogyakarta: Pustaka Belajar

Santosa, Pandji. 2008. Administrasi Publik: Teori dan Aplikasi Good Governance. Bandung. Refika ADITAMA.

Sedarmayanti. 2007. good governance (kepemerintahan yang baik) dan Good Corporate governance (Tata kelola perusahaan yang baik). Bandung: Mandar Maju 
Analisis Tata Kelola Ruang Terbuka Hijau terhadap Pembangunan Kota di Kabupaten Majene

Pasolong, Harbani. 2007. Teori Administrasi Publik. Bandung : Alfabeta

Thoha, Miftah. 2007. Perilaku Organisasi. Jakarta. Raja Grafindo.

Waluyo. 2007. Manajemen Publik. Sumedang. CV.Mandar Maju.

DR.Paiman, M.Si. 2007. Pelayanan Publik dan Costumer Satisfaction. Bandung. PT.Alumni.

Sinambela, Lijan Poltak. 2006. Reformasi Pelayanan Publik: Teori, Kebijakan, dan Implementasi. Jakarta. PT.Bumi Aksara.

Moenir. 2006. Manajemen Pelayanan Umum di Indonesia. Jakarta. Bumi Aksara. Napitupulu,

Prasetyo, Bambang dan Jannah, Lina Miftahul. 2005. Metode Penelitian Kuantitatif. Depok. Rajawali Pers.

Mahmudi. 2005. Manajemen Kinerja Sektor Publik. Yogyakarta. UPP Sekolah Tinggi Ilmu Manajemen YKPN.

Adya, Atep Brata. 2004. Dasar-Dasar Pelayanan Prima. Jakarta. PT.Alex Media Komputindo.

Dunn, William N, 2003, Pengantar Analisis Kebijakan Publik, Yogyakarta: Gadjah Mada University Press.

Hasibuan, Malayu. 2002. Manajemen Sumber Daya Manusia. Jakarta. Bumi Aksara.

Yudiatmajaa, Wahyu Eko. 2012. Dinamika Administrasi Negara Kontemporer: Konsep dan Isu. Yogyakarta. Capiya Publishing. 